\title{
Primary Extrauterine Endometrial Stromal Sarcoma in the Sigmoid Colon
}

\author{
Hyun-Jin Son, Joo-Heon Kim, Dong-Wook Kang, Hye-Kyung Lee, Mee-Ja Park, Seung Yun Lee \\ Department of Pathology, Eulji University School of Medicine, Daejeon, Korea
}

An endometrial stromal sarcoma (ESS) is an uncommon uterine neoplasm, and its primary occurrence in the intestine as an extrauterine ESS (EESS) is exceedingly rare. We hereby report a primary EESS arising in the sigmoid colon with a review of the literature. A 52-year-old woman presented with bloody stool and underwent a colon fiberscopy, which revealed a fungating mass obstructing the lumen at the distal sigmoid. A laparoscopic low anterior resection was performed, and an umbilicated polypoid mass was identified; on section, it had infiltrated the mesocolic fat and measured $3.8 \mathrm{~cm} \times 2.5 \mathrm{~cm}$. The tumor showed geographic sheets or nests composed of relatively monotonous stromal cells, expansion or infiltration to the proper muscle and mesocolic fat, and extensive lymphovascular invasion and metastasis to regional lymph nodes and the pelvic peritoneum. The tumor cells were strongly and diffusely immunoreactive for CD10, but negative for c-kit, CD34, and Dog1. Two months later, a hysterectomy with a bilateral salpingo-oophorectomy was performed, and no evidence of an ESS was found in the uterus.

Keywords: Endometrial stromal sarcoma; Extrauterine; Sigmoid colon; CD10

\section{INTRODUCTION}

An endometrial stromal sarcoma (ESS), an uncommon uterine mesenchymal neoplasm, accounts for approximately $0.2 \%$ of all uterine malignancies [1]. Its occurrence at extrauterine sites is very rare, but it has been reported to occur at the ovary, bowel wall, abdomen, peritoneum, pelvis, and vagina [2]. Primary gastrointestinal involvement is rare [3-13]. We hereby present a case of a primary low-grade extrauterine ESS (EESS) in the sigmoid colon with a review of the literature. No evidence of a primary uterine ESS was found.

\section{CASE REPORT}

A 52-year-old woman was transferred from an outside clinic in

Received: December 11, 2014 - Accepted: February 6, 2015

Correspondence to: Hyun-Jin Son, M.D.

Department of Pathology, Eulji University Hospital, 95 Dunsanseo-ro,

Seo-gu, Daejeon 302-799, Korea

Tel: +82-42-611-3451, Fax: +82-42-611-3459

E-mail: shjpathol@eulji.ac.kr

(c) 2015 The Korean Society of Coloproctology

This is an open-access article distributed under the terms of the Creative Commons Attribution NonCommercial License (http://creativecommons.org/licenses/by-nc/3.0) which permits unrestricted noncommercial use, distribution, and reproduction in any medium, provided the original work is properly cited. order to evaluate the bloody stool and a pedunculated mass in the sigmoid colon that had been detected in a rigid sigmoid-scope examination. She was suffering from constipation, unspecified abdominal pain and hematochezia for a month. Her past and family histories were all unremarkable. Laboratory findings were unremarkable, except for mild anemia.

Colon fiberscopy was performed and revealed a fungating mass obstructing the lumen at the distal sigmoid colon $(20 \mathrm{~cm}$ from the anal verge) (Fig. 1A). Under the impression of colon cancer, a biopsy was taken and suggested the possibility of a gastrointestinal stromal tumor (GIST) showing uncertain malignant potential. Abdominal computed tomography showed an eccentric and irregular wall thickening with enhancement measuring about $5 \mathrm{~cm}$ and perirectal lymph node enlargement (T3 or T4aN1M0, stage IIIB) (Fig. 1B). A laparoscopic low anterior resection was carried out, and an umbilicated polypoid mass measuring about $3.8 \mathrm{~cm} \times 2.5$ $\mathrm{cm}$ was identified in the distal sigmoid colon; on serial sections, it was found to have infiltrated the mesocolic fat (Fig. 1C, D). No dilation of the proximal bowel side to the mass was identified.

On histopathologic findings, the tumor showed geographic sheets or nests expanding to or infiltrating into the proper muscle and mesocolic fat (Fig. 2A), extensive lymphovascular invasion (Fig. 2B), and metastasis to regional lymph nodes (Fig. 2C) and to the pelvic peritoneum. In spite of extensive sampling, no focus of endometriosis was found in the resected colon specimen. Uni- 

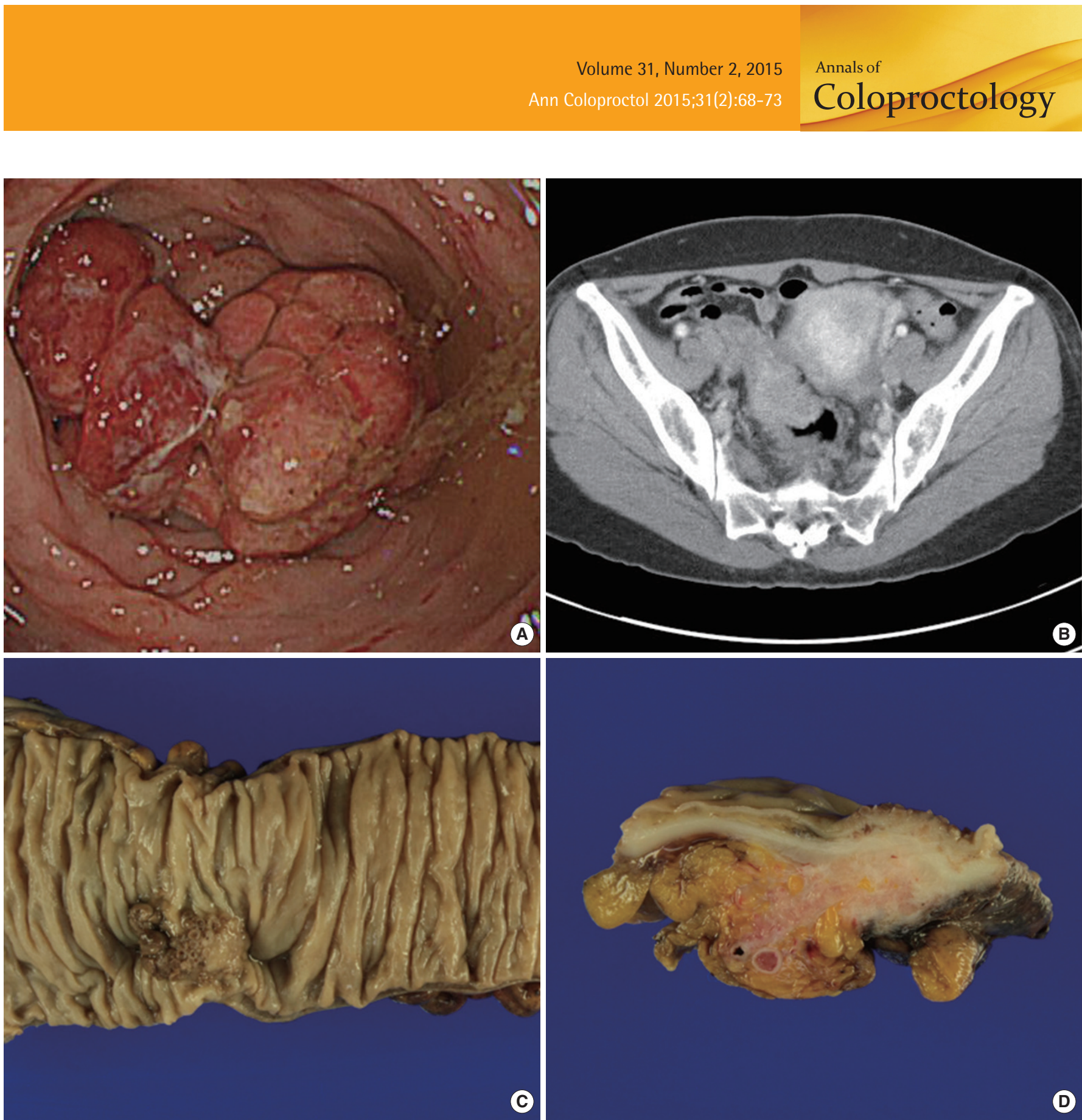

Fig. 1. (A) Colon fiberscopy reveals a fungating mass obstructing the lumen at the distal sigmoid colon (20 cm from the anal verge). (B) Contrast-enhanced axial abdomen computed tomography shows an eccentric and irregular wall thickening with enhancement in the distal sigmoid colon measuring about $5 \mathrm{~cm}$ and a pericolic lymph node enlargement. (C) Grossly, an umbilicated polypoid mass measuring about 3.8 $\mathrm{cm} \times 2.5 \mathrm{~cm}$ is identified in the distal sigmoid colon, and (D) on serial sections, it was found to have infiltrated to the mesocolic fat and to involve a regional lymph node.

formly small, bland tumor cells with rounded-ovoid nuclei, evenly dispersed chromatin, no or inconspicuous nucleoli, and scanty cytoplasm with indistinct cell borders were noticed (Fig. 2D). Small, prominent arterioles were scattered among the stromal tumor cells. No mitosis or necrosis was identified. The tumor cells were strongly and diffusely immunoreactive for CD10 (1:50, Novocastra, Newcastle, UK) (Fig. 2E), estrogen receptor (ER; 1:40, Novocastra), and progesterone receptor (PR; 1:200, Novocastra), but negative for c-kit (1:600, Dako, Carpinteria, CA, USA), CD34 (predilution, Novocastra), Dog1 (1:500, Dako), a-smooth muscle actin (1:100, Novocastra), S100 protein (1:200, Novocastra), desmin (1:50, Dako) and pan-cytokeratin (1:200, Novocastra). The Ki-67 (1:100, Dako) labeling index was 8\% (Fig. 2F).

Endometrial curettage was conducted postoperatively and showed secretory hyperplasia and no evidence of ESS. Two months later, a total abdominal hysterectomy with a bilateral sal- 


\begin{aligned} & Annals of Primary Extrauterine Endometrial Stromal Sarcoma in the Sigmoid Colon \\ & Coloproctology Hyun-Jin Son, et al. \\ & \hline\end{aligned}
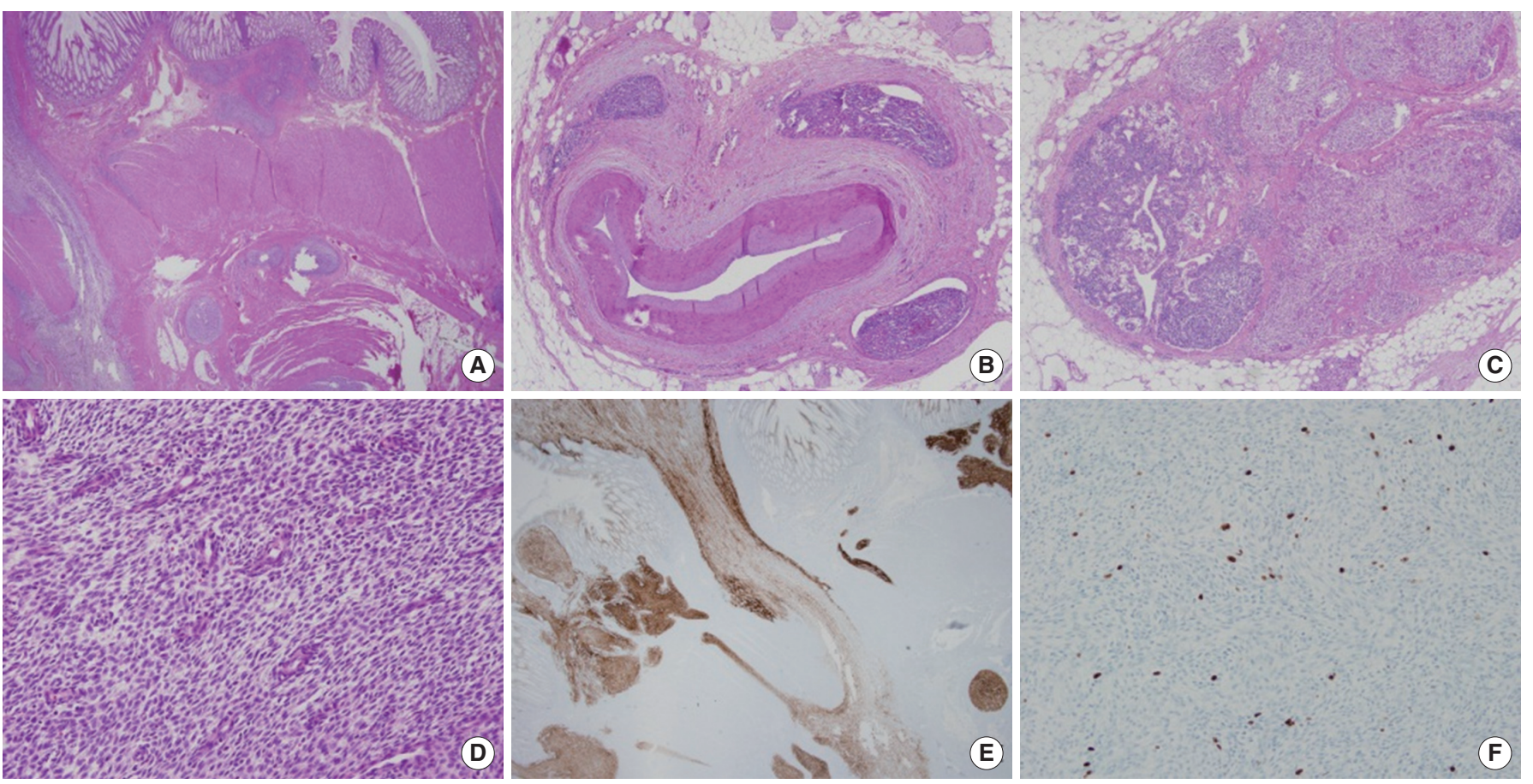

Fig. 2. (A) The tumor shows geographic sheets or nests expanding to or infiltrating into the proper muscle and mesocolic fat (H\&E, $\times 12.5)$. (B) Extensive lymphovascular invasion $(\mathrm{H} \& \mathrm{E}, \times 40)$ and $(\mathrm{C})$ metastasis to regional lymph nodes $(\mathrm{H} \& \mathrm{E}, \times 40)$ are seen. (D) Uniformly small, bland tumor cells have rounded-ovoid nuclei, evenly dispersed chromatin, no or inconspicuous nucleoli, and scanty cytoplasm with indistinct cell borders. Small, prominent arterioles are scattered among the stromal tumor cells (H\&E, $\times 200)$. (E) The tumor cells are strongly and diffusely immunoreactive for CD10 ( $\times 12.5)$. (F) The Ki-67 labeling index is $8 \%(\times 100)$.
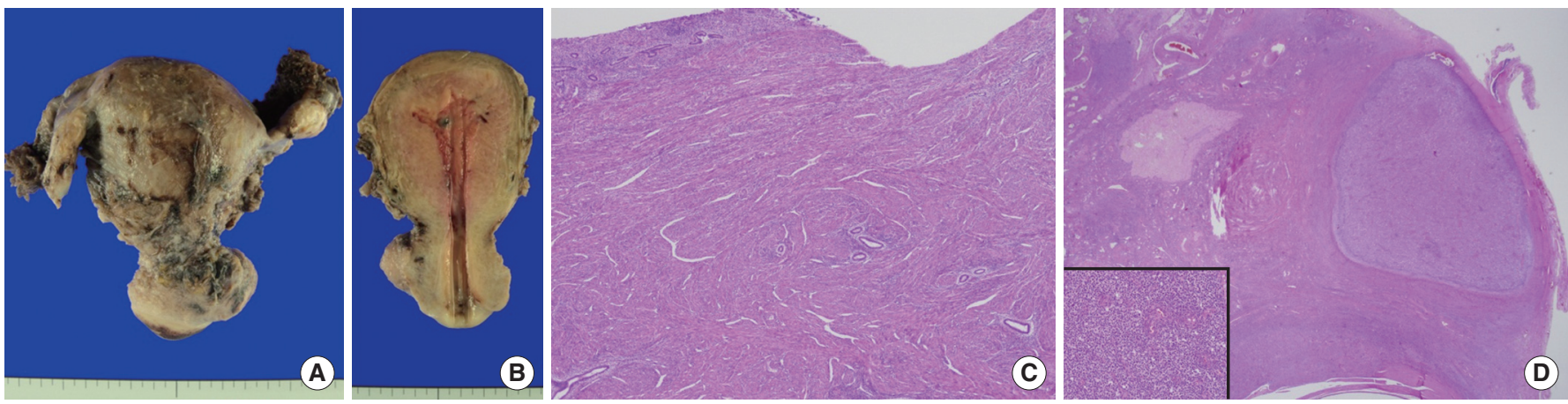

Fig. 3. (A) The uterus measures $6.0 \mathrm{~cm} \times 10.0 \mathrm{~cm} \times 4.5 \mathrm{~cm}$, and bilateral adnexae are grossly unremarkable. (B) Upon cross sectioning, the uterine wall was found to have thickened by $3.2 \mathrm{~cm}$, and an ill-defined trabeculated area with several hemorrhagic foci was revealed. (C) Microscopically, the endometrium is relatively atrophic, and the uterine wall is thickened due to adenomyosis (H\&E, $\times 40)$. (D) A microscopic focus of the endometrial stromal nodule is identified in the ovary $(\mathrm{H} \& \mathrm{E}, \times 40)$ (Inset: high power view of the endometrial stromal nodule [H\&E, $\times 200])$.

pingo-oophorectomy was performed. The uterus measured 6.0 $\mathrm{cm} \times 10.0 \mathrm{~cm} \times 4.5 \mathrm{~cm}$, and upon cross section, the uterine wall was thickened up to $3.2 \mathrm{~cm}$ and revealed an ill-defined trabeculated area with several hemorrhagic foci and a myomatous mass in the low uterine segment (Fig. 3A, B). Microscopically, it was diagnosed as adenomyosis, an intramural leiomyoma, and a relatively atrophic endometrium (Fig. 3C). Grossly, the bilateral ad- nexae were unremarkable, but microscopic foci of the endometrial stromal nodule were identified in the right and left ovaries and measured $0.6 \mathrm{~cm}$ and $0.8 \mathrm{~cm}$, respectively (Fig. 3D). However, no focus of endometriosis was found in the uterus or bilateral adnexae. The patient was alive four months after the resection with no evidence of recurrence. 


\section{DISCUSSION}

An ESS arising outside the uterus at extraovarian sites in the ab- sence of a primary uterine lesion is extremely rare, and only several case reports are present in the English literature. The abdomen and the pelvis are the most common locations for an EESS,

Table 1. Clinical and pathological features of an EESS arising in the colon

\begin{tabular}{|c|c|c|c|c|c|c|c|c|c|}
\hline $\begin{array}{l}\text { Age } \\
(\mathrm{yr})\end{array}$ & $\begin{array}{c}\text { Past } \\
\text { history }\end{array}$ & $\begin{array}{c}\text { Symptoms } \\
\text { at presentation }\end{array}$ & $\begin{array}{l}\text { Involving } \\
\text { colon site(s) }\end{array}$ & $\begin{array}{l}\text { Gross findings, } \\
\text { colon }\end{array}$ & $\begin{array}{c}\text { Foci of } \\
\text { endometriosis }\end{array}$ & Treatment & Follow-up & Dissemination & Ref. \\
\hline 80 & TAH, BSO & $\begin{array}{l}\text { Rectal bleeding } \\
\text { and chronic } \\
\text { discharge }\end{array}$ & Sigmoid colon & $\begin{array}{l}\text { 5-cm Mass involving } \\
\text { mucosa, muscularis, } \\
\text { and peritoneum }\end{array}$ & Ovary & $\begin{array}{l}\text { Low anterior } \\
\text { colon resection }\end{array}$ & $\begin{array}{l}\text { NED, } \\
4 \mathrm{yr}\end{array}$ & Local & [4] \\
\hline 42 & $\begin{array}{l}\text { Lung cancer, } \\
\text { chemotherapy }\end{array}$ & $\begin{array}{l}\text { Difficult defecation, } \\
\text { rectal bleeding }\end{array}$ & Sigmoid colon & $\begin{array}{l}\text { Multiple 1- to 3-cm } \\
\text { nodular masses } \\
\text { involving mucosa } \\
\text { to pericolic fat }\end{array}$ & $\begin{array}{l}\text { Sigmoid } \\
\text { colon }\end{array}$ & $\begin{array}{l}\text { Rectosigmoidectomy, } \\
\text { total } \\
\text { hysterectomy, } \\
\text { BSO }\end{array}$ & $\begin{array}{l}\text { NED, } \\
1 \mathrm{yr}\end{array}$ & $\begin{array}{l}\text { Local } \\
\text { (omentum, } \\
\text { left adnexa) }\end{array}$ & [5] \\
\hline 48 & $\begin{array}{l}\text { Subtotal } \\
\text { hysterectomy } \\
\text {-> myoma, } \\
\text { LSO -> } \\
\text { endometriosis }\end{array}$ & $\begin{array}{l}\text { Difficult } \\
\text { defecation and } \\
\text { tenesmus }\end{array}$ & Sigmoid colon & $\begin{array}{l}\text { Multinodular masses } \\
\text { of } 1-3 \mathrm{~cm} \text { involving } \\
\text { the whole layer of } \\
\text { the intestine and } \\
\text { extending to the } \\
\text { urinary bladder } \\
\text { and ureter }\end{array}$ & $\begin{array}{l}\text { Left ovary } \\
\text { sigmoid } \\
\text { colon }\end{array}$ & $\begin{array}{l}\text { Segmental } \\
\text { resection }\end{array}$ & $\begin{array}{l}\text { NED, } \\
4 \mathrm{mo}\end{array}$ & $\begin{array}{l}\text { Local } \\
\text { (mesentery, } \\
\text { urinary } \\
\text { bladder, } \\
\text { ureter) }\end{array}$ & {$[6]$} \\
\hline 46 & $\begin{array}{l}\text { TAH, RSO } \\
\text {-> leiomyomas, } \\
\text { normal adnexa }\end{array}$ & Stenosing process & $\begin{array}{l}\text { Rectosigmoid } \\
\text { colon }\end{array}$ & $\begin{array}{l}\text { A tumor } 6 \mathrm{~cm} \text { in } \\
\text { diameter }\end{array}$ & $\begin{array}{l}\text { Rectosigmoid } \\
\text { colon }\end{array}$ & $\begin{array}{l}\text { Oophorectomy, } \\
\text { tumorectomy, } \\
\text { omentectomy, } \\
\text { resection of colon }\end{array}$ & $\begin{array}{l}\text { NED, } \\
11 \mathrm{mo}\end{array}$ & $\begin{array}{l}\text { Local (ovary, } \\
\text { omentum) }\end{array}$ & [7] \\
\hline 38 & $\begin{array}{l}\text { Ovarian } \\
\text { cystectomy -> } \\
\text { endometriosis, } \\
\text {-> TAH, BSO }\end{array}$ & $\begin{array}{l}\text { Abdominal pain } \\
\text { and pressure }\end{array}$ & $\begin{array}{l}\text { Ascending } \\
\text { and transverse } \\
\text { colon, terminal } \\
\text { ileum }\end{array}$ & $\begin{array}{l}\text { A large multilobular } \\
\text { mass involving } \\
\text { the transverse, } \\
\text { ascending colon and } \\
\text { the terminal ileum }\end{array}$ & Ovary, colon & $\begin{array}{l}\text { Partial ileal resection, } \\
\text { resection of the } \\
\text { transverse and } \\
\text { ascending colon } \\
\text {-> chemotherapy }\end{array}$ & NED & $\begin{array}{l}\text { Local (falciform, } \\
\text { gastrocolic } \\
\text { ligament, } \\
\text { mesentery, } \\
\text { pelvis) }\end{array}$ & [8] \\
\hline 50 & $\begin{array}{l}\text { TAH, RSO -> } \\
\text { endometriosis }\end{array}$ & Abdominal pain & $\begin{array}{l}\text { Transverse colon, } \\
\text { junction of } \\
\text { descending } \\
\text { and sigmoid } \\
\text { colon }\end{array}$ & $\begin{array}{l}\text { A large grapelike } \\
\text { tumor, with } \\
\text { individual nodular } \\
\text { areas } 2 \mathrm{~cm} \times 2.5 \mathrm{~cm}\end{array}$ & Ovary & $\begin{array}{l}\text { LSO, radical } \\
\text { omentectomy } \\
\text {-> hormonal therapy }\end{array}$ & NED & $\begin{array}{l}\text { Local } \\
\text { (omentum) }\end{array}$ & [8] \\
\hline 61 & None & Epigastric pain & $\begin{array}{l}\text { Rectosigmoid } \\
\text { colon }\end{array}$ & $\begin{array}{l}\text { An } 2.7-\mathrm{cm} \text { polypoid } \\
\text { mass with stenosis } \\
\text { of the lumen } \\
\text { involving all layers } \\
\text { of the rectal wall }\end{array}$ & $\begin{array}{l}\text { Posterior wall } \\
\text { of right broad } \\
\text { ligament }\end{array}$ & $\begin{array}{l}\text { Resection of } \\
\text { rectosigmoid colon }\end{array}$ & $\begin{array}{l}\text { NED, } \\
30 \text { mo }\end{array}$ & None & [9] \\
\hline 42 & None & $\begin{array}{l}\text { Fever and } \\
\text { abdominal pain }\end{array}$ & Rectum & $\begin{array}{l}\text { Massive transmural } \\
\text { infiltration involving } \\
\text { mucosa, which } \\
\text { was polypoid and } \\
\text { ulcerated }\end{array}$ & $\begin{array}{l}\text { Adventitial } \\
\text { rectal layer }\end{array}$ & $\begin{array}{l}\text { TAH, BSO, } \\
\text { omentectomy, } \\
\text { colorectal resection } \\
\text {-> chemotherapy }\end{array}$ & $\begin{array}{l}\text { NED, } \\
20 \text { mo }\end{array}$ & $\begin{array}{l}\text { Local (serosal } \\
\text { uterine, } \\
\text { parametrial, } \\
\text { peritoneal } \\
\text { lymphatics) }\end{array}$ & [10] \\
\hline 63 & NA & NA & Rectum & 2-cm Polypoid mass & NA & $\begin{array}{l}\text { Partial colectomy } \\
\text {-> radiation therapy }\end{array}$ & $\begin{array}{c}\text { Recurrent, } \\
3 \mathrm{yr}\end{array}$ & , NA & [11] \\
\hline 52 & None & $\begin{array}{l}\text { Constipation, } \\
\text { unspecified } \\
\text { abdominal pain, } \\
\text { hematochezia }\end{array}$ & Sigmoid colon & $\begin{array}{l}\text { An umbilicated polypoid } \\
\text { mass measuring } \\
\text { about } 3.8 \mathrm{~cm} \times 2.5 \mathrm{~cm} \\
\text { involving the whole } \\
\text { layer of the intestine to } \\
\text { pericolic fat }\end{array}$ & Not identified & $\begin{array}{l}\text { Laparoscopic } \\
\text { low anterior } \\
\text { resection } \\
\text { TAH, BSO }\end{array}$ & $\begin{array}{l}\text { NED, } \\
4 \mathrm{mo}\end{array}$ & $\begin{array}{l}\text { Local (pelvic } \\
\text { peritoneum, } \\
\text { both ovaries) }\end{array}$ & $\begin{array}{l}\text { Present } \\
\text { case }\end{array}$ \\
\hline
\end{tabular}

EESS, extrauterine endometrial stromal sarcoma; TAH, total abdominal hysterectomy; BSO, bilateral salpingo-oophorectomy; NED, no evidence of disease; LSO, left salpingo-oophorectomy; RSO, right salpingo-oophorectomy; NA, not available. 
and its occurrence in the colonic wall is exceedingly rare, with only 9 reported cases in the literature (Table 1) [4-11]. Together with our case, 10 cases of an EESS in the colon have been reported, and the ages of the patients ranged from 38 to 80 years (mean, 52.2 years). The symptoms at presentation were abdominal pain, difficult defecation, hematochezia and alteration of bowel habits. The sigmoid colon and rectum are the most common sites of occurrence ( 9 out of 10 cases), which reflects the areas of the bowel having the highest incidence of endometriosis and the anatomic proximity to the ovary. Local dissemination was discovered at the time of the colonic resection in 8 out of the 10 cases, but no recurrence, except for one case, was found during the follow-up period (4 months to 4 years).

Associated foci of endometriosis in the colonic wall, peritoneal cavity or other sites were documented in 8 out of 9 previously reported cases. In our case, in spite of extensive sampling, no histological evidence of endometriosis was found in the specimens of the resected colon and both ovaries. Because the foci of endometriosis are almost always present in the vicinity of the EESS, one suggest that the primary EESS probably originated from an ectopic endometrial stroma of endometriosis, but our case implies that the mere absence of endometriosis does not preclude a primary EESS at that site. The pathogenesis of a primary EESS with no evidence of endometriosis is indefinite. The possibility is mentioned that the tumor might have originated from gland-poor foci of endometriosis [2], de novo from the peritoneal surface or the coelomic or subcoelomic multipotential epithelium $[14,15]$.

Malignant transformation is a rare, but well-known, complication of endometriosis, and most of these malignant neoplasms are endometrial adenocarcinomas (EAs). Yantiss et al. [11] reported 17 cases of gastrointestinal endometriosis complicated by neoplasms or precancerous changes. The neoplasms comprised 8 cases of EA, 4 cases of a Müllerian adenosarcoma, one case of an endometrioid adenofibroma of borderline malignancy with a carcinoma in situ, and one case of an EESS.

An unexpected location and an unusual presentation of an EESS may make the diagnosis challenging, despite classic histologic features. The GIST is the main differential diagnosis in the cases of an EESS arising in colon. The typical spiral arteriole-like vessels and perivascular whorl arrangement of monotonous spindle tumor cells should raise suspicion of an ESS. Immunohistochemistry is useful to distinguish these two entities. A GIST is known to be positively immunoreactive for c-kit, but an ESS is not. Moreover, an ESS shows diffuse immunoreactivity for CD10, ER, and PR. In our case, the tumor cells were strongly and diffusely immunoreactive for CD10, ER, and PR, but negative for c-kit.

In summary, we report a rare case of a primary EESS arising in the sigmoid colon in a 52-year-old woman with local dissemination to the pelvic peritoneum and both ovaries. Endometriosis was not found in specimens of the resected colon and both ovaries.

\section{CONFLICT OF INTEREST}

No potential conflict of interest relevant to this article was reported.

\section{REFERENCES}

1. Tavassoli FA, Devilee P. World Health Organization Classification of Tumors. Pathology and genetics of tumors of the breast and female genital organs. Lyon: IARC Press; 2003.

2. Masand RP, Euscher ED, Deavers MT, Malpica A. Endometrioid stromal sarcoma: a clinicopathologic study of 63 cases. Am J Surg Pathol 2013;37:1635-47.

3. Jin M, Reynolds JP, Odronic SI, Wakely PE Jr. Primary gastric extra-uterine endometrial stromal sarcoma. Ann Diagn Pathol 2014; 18:187-90.

4. Ayuso A, Fadare O, Khabele D. A case of extrauterine endometrial stromal sarcoma in the colon diagnosed three decades after hysterectomy for benign disease. Case Rep Obstet Gynecol 2013; 2013:202458.

5. Chen CW, Ou JJ, Wu CC, Hsiao CW, Cheng MF, Jao SW. Highgrade endometrial stromal sarcoma arising from colon endometriosis. Int J Colorectal Dis 2007;22:1551-3.

6. Cho HY, Kim MK, Cho SJ, Bae JW, Kim I. Endometrial stromal sarcoma of the sigmoid colon arising in endometriosis: a case report with a review of literatures. J Korean Med Sci 2002;17:412-4.

7. Kovac D, Gasparovic I, Jasic M, Fuckar D, Dobi-Babic R, Haller H. Endometrial stromal sarcoma arising in extrauterine endometriosis: a case report. Eur J Gynaecol Oncol 2005;26:113-6.

8. Baiocchi G, Kavanagh JJ, Wharton JT. Endometrioid stromal sarcomas arising from ovarian and extraovarian endometriosis: report of two cases and review of the literature. Gynecol Oncol 1990; 36:147-51.

9. Mourra N, Tiret E, Parc Y, de Saint-Maur P, Parc R, Flejou JF. Endometrial stromal sarcoma of the rectosigmoid colon arising in extragonadal endometriosis and revealed by portal vein thrombosis. Arch Pathol Lab Med 2001;125:1088-90.

10. Bosincu L, Massarelli G, Cossu Rocca P, Isaac MA, Nogales FF. Rectal endometrial stromal sarcoma arising in endometriosis: report of a case. Dis Colon Rectum 2001;44:890-2.

11. Yantiss RK, Clement PB, Young RH. Neoplastic and pre-neoplastic changes in gastrointestinal endometriosis: a study of 17 cases. Am J Surg Pathol 2000;24:513-24.

12. Kim L, Choi SJ, Park IS, Han JY, Kim JM, Chu YC, et al. Endometrial stromal sarcoma of the small bowel. Ann Diagn Pathol 2008; 12:128-33.

13. Oliva E, Clement PB, Young RH. Epithelioid endometrial and endometrioid stromal tumors: a report of four cases emphasizing their distinction from epithelioid smooth muscle tumors and other oxyphilic uterine and extrauterine tumors. Int J Gynecol Pathol 2002;21:48-55.

14. Norris HJ, Taylor HB. Mesenchymal tumors of the uterus. I. A 
clinical and pathological study of 53 endometrial stromal tumors. Cancer 1966;19:755-66.
15. Lauchlan SC. The secondary Müllerian system. Obstet Gynecol Surv 1972;27:133-46. 